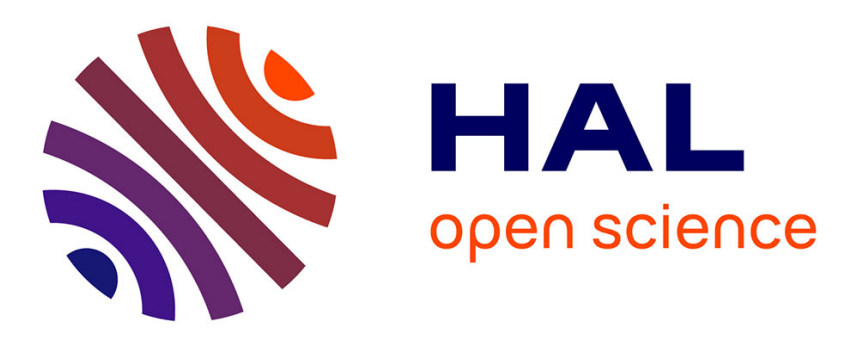

\title{
Characterization of glutathione peroxidase diversity in the symbiotic sea anemone Anemonia viridis
}

Alexis Pey, Thamilla Zamoum, Richard Christen, Pierre-Laurent Merle, Paola Furla

\section{- To cite this version:}

Alexis Pey, Thamilla Zamoum, Richard Christen, Pierre-Laurent Merle, Paola Furla. Characterization of glutathione peroxidase diversity in the symbiotic sea anemone Anemonia viridis. Biochimie, 2016, 132, pp.94 - 101. 10.1016/j.biochi.2016.10.016 . hal-01404424

\section{HAL Id: hal-01404424 https://hal.sorbonne-universite.fr/hal-01404424}

Submitted on 28 Nov 2016

HAL is a multi-disciplinary open access archive for the deposit and dissemination of scientific research documents, whether they are published or not. The documents may come from teaching and research institutions in France or abroad, or from public or private research centers.
L'archive ouverte pluridisciplinaire HAL, est destinée au dépôt et à la diffusion de documents scientifiques de niveau recherche, publiés ou non, émanant des établissements d'enseignement et de recherche français ou étrangers, des laboratoires publics ou privés. 
1 Characterization of Glutathione Peroxidase Diversity in the Symbiotic Sea Anemone

2 Anemonia viridis

3

4 Alexis Pey ${ }^{1}$, Thamilla Zamoum ${ }^{1}$, Richard Christen ${ }^{1}$, Pierre-Laurent Merle ${ }^{1 \dagger}$ and Paola Furla ${ }^{1 \S}$ 5

$6{ }^{1}$ Sorbonne Universités, UPMC Univ Paris 06, Univ Antilles, Univ Nice Sophia Antipolis, CNRS,

7 Evolution Paris Seine - Institut de Biologie Paris Seine (EPS - IBPS), 75005 Paris, France

8 Email addresses: pey@unice.fr; thamilla.zamoum@unice.fr; $\quad$ richard.christen@unice.fr;

9 furla@unice.fr

10

$11 \S$ Corresponding author:

12 P Furla, Université Nice Sophia Antipolis, UMR 7138 "Evolution Paris Seine", Équipe “'Symbiose 13 marine", 06100 Nice, France

14 E-mail: furla@unice.fr

15

16 The authors dedicate this article to the memory of their friend and colleague, Pierre-Laurent 17 Merle, who died February 1st, 2015. The scientific world has lost a man fascinated by the sea with 18 great humanity. Without his involvement at all stages of the project this work would not have been 19 possible. 
22 Cnidarians living in symbiosis with photosynthetic dinoflagellates (commonly named 23 zooxanthellae) are exposed to high concentrations of reactive oxygen species (ROS) upon 24 illumination. To quench ROS production, both the cnidarian host and zooxanthellae express a full 25 suite of antioxidant enzymes. Studying antioxidative balance is therefore crucial to understanding 26 how symbiotic cnidarians cope with ROS production. We characterized glutathione peroxidases 27 (GPx) in the symbiotic cnidarian Anemonia viridis by analysis of their isoform diversity, their 28 activity distribution in the three cellular compartments (ectoderm, endoderm and zooxanthellae) and 29 their involvement in the response to thermal stress. We identified a GPx repertoire through a 30 phylogenetic analysis showing 7 GPx transcripts belonging to the A. viridis host and 4 GPx 31 transcripts strongly related to Symbiodinium sp. The biochemical approach, used for the first time 32 with a cnidarian species, allowed the identification of GPx activity in the three cellular 33 compartments and in the animal mitochondrial fraction, and revealed a high GPx electrophoretic 34 diversity. The symbiotic lifestyle of zooxanthellae requires more GPx activity and diversity than 35 that of free-living species. Heat stress induced no modification of GPx activities. We highlight a 36 high GPx diversity in A. viridis tissues by genomic and biochemical approaches. GPx activities 37 represent an overall constitutive enzymatic pattern inherent to symbiotic lifestyle adaptation. This 38 work allows the characterization of the GPx family in a symbiotic cnidarian and establishes a 39 foundation for future studies of GPx in symbiotic cnidarians.

\section{Keywords}

43 Oxidative stress; Cnidaria; Glutathione Peroxidase; Symbiosis; Zooxanthellae 
For a long time, symbiotic cnidarians have ensured their evolutionary success by a life in symbiosis with dinoflagellates of the genus Symbiodinium, also commonly named zooxanthellae. Zooxanthellae are endosymbionts, living in the animal host cells. This intimate association offers advantages for both partners. On the one hand, zooxanthellae find a protected and stable environment and the animal cells actively provide inorganic compounds such as nitrogen, phosphorus and sulfate used for the algal photosynthetic activity [1]. On the other hand, some of the organic compounds produced by algal photosynthesis are transferred from the zooxanthellae to the animal host, which makes them less dependent on predation. Such metabolic relationships also confer costs and disadvantages, which must be tolerated by both partners. In particular, when photosynthesis occurs, a great amount of molecular oxygen is produced. Although oxygen is unavoidable, it can be transformed and reduced into harmful reactive oxygen species (ROS; [2]). As a result, the animal tissues face both an intense diurnal hyperoxic state and consequently a concomitant ROS overproduction [3-6]. Consequently, both partners must have the pathways for cross-regulating many metabolic processes, especially those involved in ROS resistance [7-9]. This explains why symbiotic cnidarians are considered interesting biological models for investigating ROS resistance.

The study of ROS synthesis and removal in these organisms is also of great environmental interest. Environmental perturbations (especially variations in temperature and UV radiation) often induce symbiosis breakdown, a process commonly called bleaching (for reviews see [10-12]). Under stressful conditions, zooxanthellae can be eliminated from or exit the host through different cellular processes involving oxidative stress. Usually, both the cnidarian host and zooxanthellae express a full suite of antioxidant enzymes to avoid damage from ROS production. But under stressful conditions, imbalance between ROS overproduction and antioxidant defenses leads to cellular damage (lipid peroxidation, protein oxidation, DNA degradation) resulting in the disruption of the symbiotic association [13-16].

Many reports corroborate the fact that these symbiotic cnidarians possess extensive and specific enzymatic and non-enzymatic antioxidant defenses [17]. In previous work, we focused our interest on superoxide dismutases (SOD, EC 1.15.1.1), which are at the forefront of the defenses against ROS by the dismutation of superoxide anions to $\mathrm{H}_{2} \mathrm{O}_{2}$ and $\mathrm{O}_{2}[4,14,18]$. At low levels, hydrogen peroxide may play important roles in different cellular signaling pathways and be catabolized by 
cytotoxic molecule, diffusing through biological membranes and therefore causing damage far from

80 its original location. Therefore, subsequent antioxidant systems are needed to counteract potential $81 \mathrm{H}_{2} \mathrm{O}_{2}$ accumulation and cytotoxicity [20]. Within most cellular defense systems, the enzymes 82 glutathione peroxidase (GPx, EC 1.11.1.9) and catalase (CAT, EC 1.11.1.6) are the major 83 degradation enzymes of peroxides and organic peroxides. GPx inhibits production of high levels of oxidant free radicals, such as the hydroxyl radicals derived from $\mathrm{H}_{2} \mathrm{O}_{2}$ and alkoxyl radicals derived from organic peroxides. CAT has a direct effect on $\mathrm{H}_{2} \mathrm{O}_{2}$ through a dismutation reaction [2]. GPx and CAT can be considered as the essential partners of SOD, directing the flow of superoxide radicals towards the formation of water molecules. Thus, the cytotoxic action of SOD depends on the equilibrium between SOD, GPx and CAT, confirming the importance of this balance in maintaining cellular integrity and function.

The GPx family (EC.1.11.1.9) is known to present an ubiquitous distribution within the 'tree of life' and to possess a high variety of isoforms [21]. For example, in mammals, there are up to 8 isoforms of GPx with specific cellular and subcellular localizations and activities [21,22,23]. In cnidarian species, Hawkridge et al. [24] localized GPx proteins in the sea anemone Anemonia viridis and in their symbiotic algae with immunocytochemical techniques. Moreover, previous transcriptomic studies on A. viridis, revealed that some isoforms of glutathione peroxidases were up-regulated in symbiotic specimens vs. aposymbiotic ones [25], and down-regulated in response to thermal stress [26]. These patterns suggested an important role for GPx enzymes in maintenance of the cnidariandinoflagellate symbiosis. Thus, to gain further insights into the cnidarians-dinoflagelatte symbiosis, studies of the activity of GPx proteins, and their role in symbiosis maintenance and disruption are necessary. In this study, we characterized the GPx isoforms in the symbiotic cnidarian A. viridis, by analysis of their isoform diversity and their activity distribution in the three cellular compartments ectoderm, endoderm and freshly isolated zooxanthellae - and in mitochondria. In addition, we compared the influence of the symbiotic lifestyle on the zooxanthellae by comparing the GPx activities of freshly isolated zooxanthellae to those of cultured zooxanthellae. Furthermore, we investigated the induction of GPx activity in response to thermal stress. 
All chemicals were purchased from Sigma-Aldrich (St. Louis, MO).

\subsection{Biological material and experimental design}

112 Specimens of the Mediterranean sea anemone Anemonia viridis (Forskål 1775) were collected from 113 'Baie des Croutons' (Antibes, France) and maintained in a closed-circuit natural seawater aquarium.

114 Half the volume of seawater was exchanged with fresh seawater once a week and the temperature 115 was kept at $20^{\circ} \mathrm{C} \pm 0.5^{\circ} \mathrm{C}$. Artificial light was provided by metal halide lamp (HQI-TS $400 \mathrm{~W}$, 116 Philips), with a photosynthetic photo flux density of $200 \mu \mathrm{mol}$ photons $\mathrm{m}^{-2} \mathrm{~s}^{-1}$ and a $12 \mathrm{~h}: 12 \mathrm{~h}$ 117 photoperiod. Specimens were fed once a week with extracts of frozen adults of Artemia salina. For 118 the thermal stress experiment, three aquaria, each containing one specimen of $A$. viridis, were 119 heated from $20^{\circ} \mathrm{C}$ (control temperature) to $29^{\circ} \mathrm{C}$ (stress temperature) within 2 hours and maintained at this maximal temperature for 15 days. For glutathione peroxidase (GPx) activities, 3-4 tentacles were sampled from each specimen at day 0 (control condition), and after 1, 2, 5, 7, 9 and 15 days of consecutive thermal stress. Cultured zooxanthellae were originally extracted from A. viridis, maintained in $\mathrm{f} / 2$ medium [27] at $\mathrm{pH} 8.2$ and incubated at $26^{\circ} \mathrm{C} \pm 0.1^{\circ} \mathrm{C}$ under an irradiance of $100 \mu \mathrm{mol}$ photons $\mathrm{m}^{-2} \mathrm{~s}^{-1}$ (Sylvania Gro-Lux, Loessnitz, Germany), on a 12h:12h photoperiod.

125 Stock cultures were transferred monthly.

All experiments were conducted in accordance with the NIH guidelines for the care and handling of experimental animals (NIH publication no. 85-23, revised 1985). and the directive of the European Communities Council (2010/63/EU).

\subsection{Tissue separation and protein extraction}

The protocol used (adapted from [28]) allowed the specific separation and extraction of soluble proteins from the three tissue compartments of A. viridis: ectoderm (C), endoderm (D), and freshly isolated zooxanthellae. Soluble proteins from 3 independent flasks of cultured zooxanthellae were

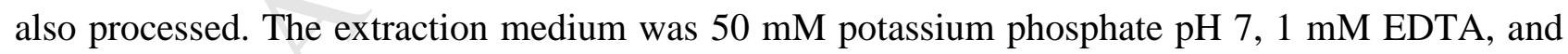
1/1000 dilution of a protease inhibitor cocktail (P-8340). The protein concentrations obtained in the extracts were determined using the Bradford method [29], with the Bio-Rad Protein Assay reagent and bovine serum albumin as standard.

\subsection{A. viridis mitochondrial enrichment}

140 The enrichment technique for the animal mitochondrial fraction was specifically developed with $A$. viridis. Fifteen tentacles were soaked in cold enrichment buffer (sucrose $450 \mathrm{mM}, \mathrm{KCl} 100 \mathrm{mM}$, 
$\mathrm{NaCl} 50 \mathrm{mM}$, EGTA $3 \mathrm{mM}$, HEPES $30 \mathrm{mM}, \mathrm{K}_{2} \mathrm{HPO}_{4} 2 \mathrm{mM}$, pH 7.6) with $0.5 \%$ fatty acid free and

$14310 \mu \mathrm{g} \mathrm{ml}^{-1}$ protease inhibitor cocktail, and homogenized using a glass homogenizer. Homogenate 144 was centrifuged at $3,000 \mathrm{xg}$ for $10 \mathrm{~min}$ at $4^{\circ} \mathrm{C}$ to remove zooxanthellae and the supernatant was 145 recovered for a second centrifugation at 3000xg for $10 \mathrm{~min}$. The resulting supernatant, containing 146 the animal mitochondrial fraction without zooxanthellae, was recovered and centrifuged at 147 15,000xg for $10 \mathrm{~min}$. The pellet, containing mitochondria, was resuspended in the cold enrichment 148 buffer and mitochondrial membranes were broken by pipette stirring.

\subsection{Spectrophotometric measurement of GPx activity}

151 GPx activity (selenium-dependent and non-selenium-dependent) was measured according to the method of Paglia and Valentine [30] and Weydert and Cullen [31]. This method is based on the GPx catalytic oxidation of glutathione by cumene hydroperoxide in the presence of glutathione reductase and NADPH. Oxidized glutathione formed by the GPx reaction $\left(\mathrm{H}_{2} \mathrm{O}_{2}+2 \mathrm{GSH} \rightarrow \mathrm{GSSG}\right.$ $+2 \mathrm{H}_{2} \mathrm{O}$ ) is continuously reduced by glutathione reductase activity (GSSG $+\mathrm{NADPH}+\mathrm{H}^{+} \rightarrow$ $\left.2 \mathrm{GSH}+\mathrm{NADP}^{+}\right)$. GPx activity was therefore calculated from the decrease in NADPH absorbance at $340 \mathrm{~nm}$ over $10 \mathrm{~min}$. Samples containing $100 \mu \mathrm{g}$ of protein were added into the assay mixture and the reaction was initiated by the addition of the cumene hydroperoxide. The assay mixture included $0.5 \mathrm{mM}$ cumene hydroperoxide (247502), $10 \mathrm{mM} \mathrm{GSH} \mathrm{(G-4251),} 30 \mathrm{mM}$ sodium azide (S-2002), $3.6 \mathrm{mM}$ NADPH (N-7505) and $5 \mathrm{u} / \mathrm{ml}$ glutathione reductase (G-3664) in $50 \mathrm{mM}$ phosphate buffer $\mathrm{pH}$ 7.6. GPx units, defined as the degradation of $1 \mu \mathrm{mol}$ of NADPH per minute, were calculated using a molar extinction coefficient for NADPH at $340 \mathrm{~nm}$ of $6.22 \mathrm{mM}^{-1}$ and normalized to mg total protein.

\subsection{Electrophoresis separation and activity staining of GPX.}

GPx activities in each tissue compartment were monitored by $10 \%$ non-denaturing polyacrylamide gel electrophoresis (PAGE) and GPx isoforms were highlighted by staining the gel with 3-(4,5dimethylthiazol-2-yl)-2,5-diphenyltetrazolium bromide (MTT), as described by Lin et al. [32]. The gel was loaded with $100-200 \mu \mathrm{g}$ of soluble protein, depending of the animal compartment. GPx from bovine erythrocytes (G-6137) was used as the internal standard (50 mU per lane). After electrophoretic separation, the gel were equilibrated for $15 \mathrm{~min}$ in tris $\mathrm{HCl} 50 \mathrm{mM}, \mathrm{pH} 7.7$ at $4^{\circ} \mathrm{C}$, and incubated in GSH with $\mathrm{H}_{2} \mathrm{O}_{2}$ solution (13 mM GSH, $0.004 \% \mathrm{H}_{2} \mathrm{O}_{2}$, tris $\mathrm{HCl} 50 \mathrm{mM}, \mathrm{pH}$ 7.7)

173 for $10 \mathrm{~min}$ at $4^{\circ} \mathrm{C}$ in the dark. GPx activities were revealed by soaking the gel in the dark for $5 \mathrm{~min}$ 174 in a solution of $24 \mathrm{mM}$ MTT (M-2128), $160 \mathrm{mM}$ phenazine methosulfate (P-9625) and tris $\mathrm{HCl} 50$ $175 \mathrm{mM}, \mathrm{pH}$ 7.7. When achromatic bands began to form, the stain was poured off and rinsed 176 extensively with double-distilled $\mathrm{H}_{2} \mathrm{O}$. Achromatic bands demonstrated the presence of GPx 
activity.

179 2.6. A. viridis transcriptome production and cnidarian genes encoding GPx sequences

180 Total RNAs of 12 independent tentacle tissue samples were extracted from two specimens of $A$.

181 viridis. After extraction, cleaning and quality checks of mRNA, 3 to 5 independent lanes of paired182 end HiSeq Illumina sequencing were done. All R1 and R2 fastq files were pooled and Illumina 183 adapters removed with Trimmomatic software [33]. A complete transcriptome was generated by 184 Trinity [34]. This generated 554092 alternative transcripts, corresponding to 331933 "genes".

185 A. viridis genes encoding GPx sequences were isolated from the transcriptome by Blastn using 186 Homo sapiens GPx family gene sequences. Data validation was then performed by tBLASTx and 187 tBLASTn searches in the databases at NCBI (National Center for Biotechnology Information). GPx 188 sequences from Nematostella vectensis, Acropora digitifera and its symbiont, Symbiodinium sp. 189 (clade A and type B1) were isolated from transcriptome or genome public databases (detailed in 190 table 1), using $H$. sapiens and A. viridis GPx family gene sequences, by the same procedure. Gene 191 analysis was completed via identification of the presence of the Sec codon, the oligomerization 192 interface and the features to determine thioredoxin specificity in the isolated A. viridis GPx 193 sequences [35,36]. A. viridis sequences were deposited in the NCBI GenBank database (NCBI 194 accession numbers in Table 1). 
196 Table 1: Cnidarian GPx homologs identified by Blast searches in available transcriptome and genome databases

\begin{tabular}{|c|c|c|c|c|c|c|}
\hline Taxons & $\begin{array}{l}\text { Name used in } \\
\text { the phylogenetic analysis }\end{array}$ & Database ID & $\begin{array}{l}\text { Database } \\
\text { Source }\end{array}$ & $\begin{array}{l}\text { Database } \\
\text { References }\end{array}$ & MW* & $\begin{array}{c}\text { Presence of } \\
\text { Seleno-cystein site }\end{array}$ \\
\hline \multirow[t]{5}{*}{ Acropora digitifera } & A.digitiferaGPxa & adi_EST_assem_4930 & Transcriptome & {$[37]$} & 188 & $+/+$ \\
\hline & A.digitiferaGPxb & adi_EST_assem_6302 & Transcriptome & {$[37]$} & 231 & $+/+$ \\
\hline & A.digitiferaGPxc & $\begin{array}{l}\text { adi_EST_assem_1023 } \\
8\end{array}$ & Transcriptome & {$[37]$} & 228 & $+/+$ \\
\hline & A.digitiferaGPxd & adi_EST_assem_2566 & Transcriptome & [37] & 191 & $-/-$ \\
\hline & A.digitiferaGPxe & adi_EST_assem_811 & Transcriptome & {$[37]$} & 204 & $+/-$ \\
\hline \multirow[t]{5}{*}{ Nematostella vectensis } & N.vectensisGPxa & XP_001641220.1 & Genome & {$[38]$} & 203 & $+/+$ \\
\hline & N.vectensisGPxb & XP_001641323.1 & Genome & {$[38]$} & 221 & $-/+$ \\
\hline & N.vectensisGPxc & XP_001641219.1 & Genome & {$[38]$} & 230 & $+/+$ \\
\hline & N.vectensisGPxd & XP_001625812.1 & Genome & {$[38]$} & 193 & $-/-$ \\
\hline & N.vectensisGPxe & XP_001617695.1 & Genome & {$[38]$} & 159 & $-/-$ \\
\hline \multirow[t]{11}{*}{ Anemonia viridis } & A.viridisGPxa & TR139497** & Transcriptome & This study & 212 & $+/+$ \\
\hline & A.viridisGPxb & TR88767** & Transcriptome & This study & 206 & $+/+$ \\
\hline & A.viridisGPxc & TR176747** & Transcriptome & This study & 217 & $+/+$ \\
\hline & A.viridisGPxd & TR800** & Transcriptome & This study & 242 & $+/+$ \\
\hline & A.viridisGPxe & TR150403** & Transcriptome & This study & 233 & $+/+$ \\
\hline & A.viridisGPxf & TR74656** & Transcriptome & This study & 197 & $-/-$ \\
\hline & A.viridisGPxg & TR50351** & Transcriptome & This study & 306 & $+/+$ \\
\hline & A.viridisGPxh & TR159974** & Transcriptome & This study & 273 & $+/-$ \\
\hline & A.viridisGPxi & TR92513** & Transcriptome & This study & 192 & $-/-$ \\
\hline & A.viridisGPxj & TR146728** & Transcriptome & This study & nd & $+/-$ \\
\hline & A.viridisGPxk & TR122461** & Transcriptome & This study & 217 & $+/-$ \\
\hline Symbiodinium sp. clade A & Symbiodinium_cladeA_GPxa & kb8_rep_c49 & Transcriptome & [39] & 244 & $+/-$ \\
\hline \multirow[t]{4}{*}{ Symbiodinium sp. clade B1 } & Symbiodinium_cladeB1_Gpxa & symbB.v1.2.004888 & Genome & {$[40]$} & 544 & $+/+$ \\
\hline & Symbiodinium_cladeB1_GPxb & symbB.v1.2.008497 & Genome & {$[40]$} & 287 & $+/-$ \\
\hline & Symbiodinium_cladeB1_GPxc & symbB.v1.2.010998 & Genome & {$[40]$} & 271 & $+/-$ \\
\hline & Symbiodinium_cladeB1_GPxd & symbB.v1.2.010038 & Genome & {$[40]$} & 257 & $+/-$ \\
\hline
\end{tabular}

197 Nd: non determined because incomplete sequence ; +/-: presence or absence of selenocystein site; *:predicted molecular weight amino acid sequence,

$198 * *$ : temporary sequence assignment (genebank accession number in submission) 
2.7. Phylogenetic GPX analysis

200 Sequence analysis was conducted by aligning protein sequences of cnidarian and Symbiodinium sp.

201 GPx proteins (isolated as described previously), and animal, fungal or plant sequences obtained 202 from the Peroxibase database [41] (http://peroxibase.toulouse.inra.fr) and lists in Supplementary

203 Table 1S. The multiple sequence alignment was performed using the MUSCLE algorithm and 204 manual adjustment. After identification of the best protein substitution model predicted by ProtTest 205 3.4, maximum likelihood tree construction was performed using Seaview software [42], with 206 bootstrap support calculated using 100 bootstrapping events. The complete alignment is available 207 upon request.

209 2.8. Statistical analysis

210 Results are given as mean \pm S.E.M. The GPx activities of each compartment were compared and 211 analyzed using Kruskal-Wallis analysis followed by a Nemenyi post hoc procedure [43]. The 212 change in GPx activities during thermal stress, in each compartment, was analyzed using 213 Friedman's nonparametric two-way ANOVA. Differences were considered statistically significant 214 when $\mathrm{p}<0.05$. 


\subsection{GPx phylogenetic analysis}

218 We queried the available transcriptome of $A$. viridis for the presence of GPx sequences. We

219 identified 11 A. viridis putative GPx-encoding transcripts belonging to different GPx families

220 (Table 1). Similarity searches and detailed analyses of the phylogenetic affiliation of GPx A. viridis

221 gene sequences revealed the presence of 7 GPx transcripts belonging to the 4 main metazoan groups

222 (5 having a tetrameric structure and 2 a monomeric structure). 4 GPx transcripts strongly related to

223 Symbiodinium sp. GPx were observed (1 having a dimeric structure and 3 a monomeric structure)

224 (Fig. 1 and Table 1). The comparison with two other cnidarians, A. digitifera and N. vectensis,

225 shows a similar GPx group distribution, but no $N$. vectensis GPx related to GPx1/2 and GPx4 were

226 identified in its genome. On the other hand, the absence of selenocysteine site in A.viridis_GPxf, A.

227 digitifera_GPxd and N.vectensis_GPxd protein sequences and their predicted monomeric structure 228 confirm their close affiliation to the GPx7 group (Table 1). None of the 11 A. viridis putative GPx 229 sequences presented the resolving cysteine in the cysteine-block, which is important for thioredoxin 230 specificity (data not shown). Finally, we noticed the presence of a GPx-like fungal sequence (Fig.1) 231 and an incomplete bacterial sequence (results not shown) in the N. vectensis genome, presumably 232 resulting from cultured medium contamination. 

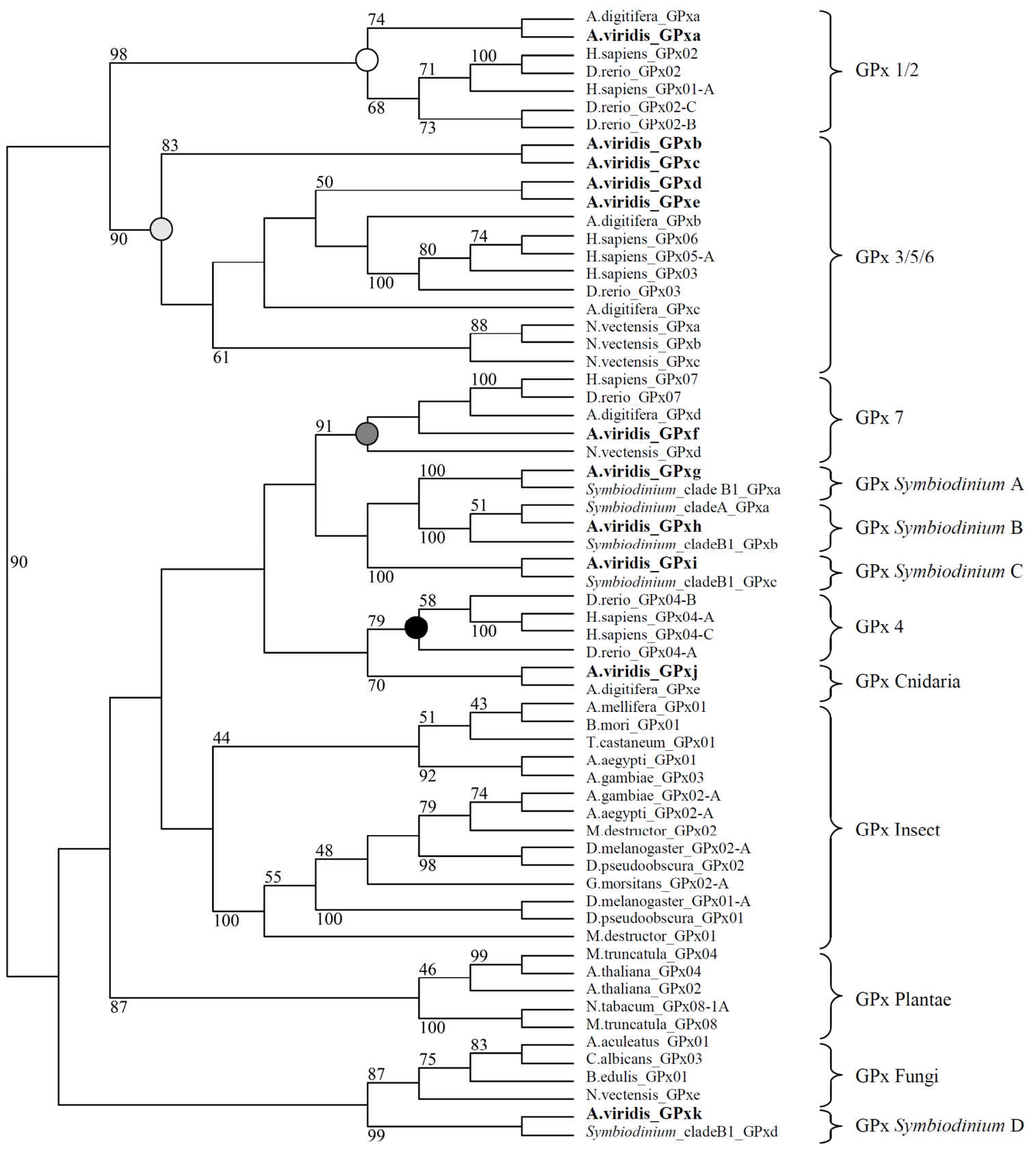

234 Fig. 1: Phylogenetic tree analysis for GPx protein. The phylogenetic tree of GPx amino acid sequences was constructed as described in Materials and Methods and was represented as an unrooted ML cladogram. Bootstrap confident values are expressed as percentages with a bootstrap

237 threshold fixed to $40 \%$. White, grey and black circles indicate the clusters related to animal GPx1/2, 238 GPx3/5/6, GPx7 and GPx4. A. viridis squared representation of the phylogenetic tree is available in 239 Supplementary Fig. 1S. 
3.2. Spectrophotometric analysis of GPx activity

243 Active GPx isoforms and tissue-specific distributions of their activity were evaluated in the animal compartments of $A$. viridis (endoderm and ectoderm), the freshly isolated zooxanthellae, and the animal mitochondrial fraction (Fig. 2). The ectodermal and endodermal fractions displayed similar GPx activities of, respectively, $38.7 \pm 5.5$ and $30.9 \pm 4.6 \mathrm{mU} \mathrm{mg}^{-1}$ protein ( $\mathrm{p}=0.31$ Nemenyi test). In contrast, the animal mitochondrial fraction displayed much reduced GPx activity, with $15.5 \pm 0.6$ $\mathrm{mU} \mathrm{mg}^{-1}$ protein (Nemenyi test, $\mathrm{p}<0.001$ ). GPx analysis of freshly isolated zooxanthellae and cultured zooxanthellae showed significant differences, with minimal activity in cultured cells $(7.2 \pm$ $0.6 \mathrm{mU} \mathrm{mg}^{-1}$ protein; Nemenyi test, $\left.\mathrm{p}<0.001\right)$.

A

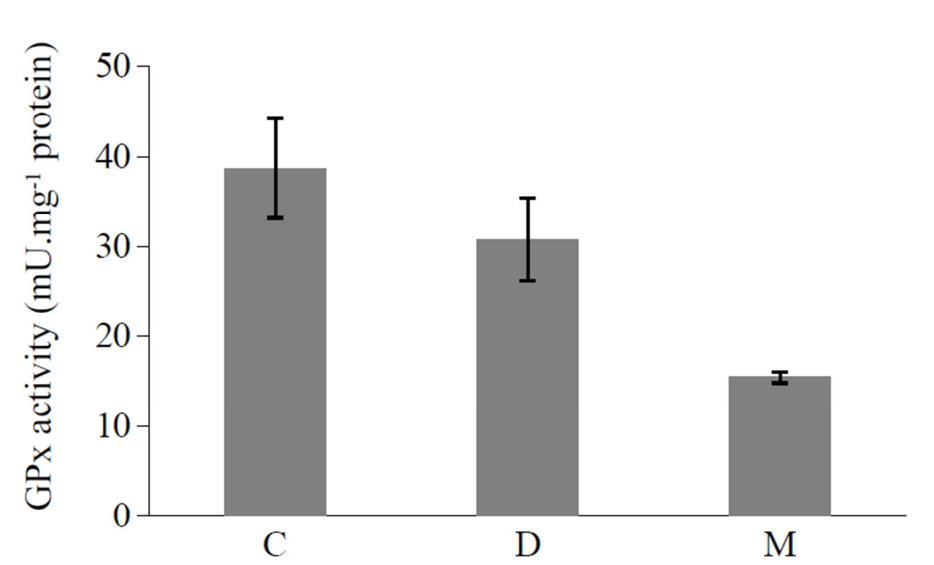

B

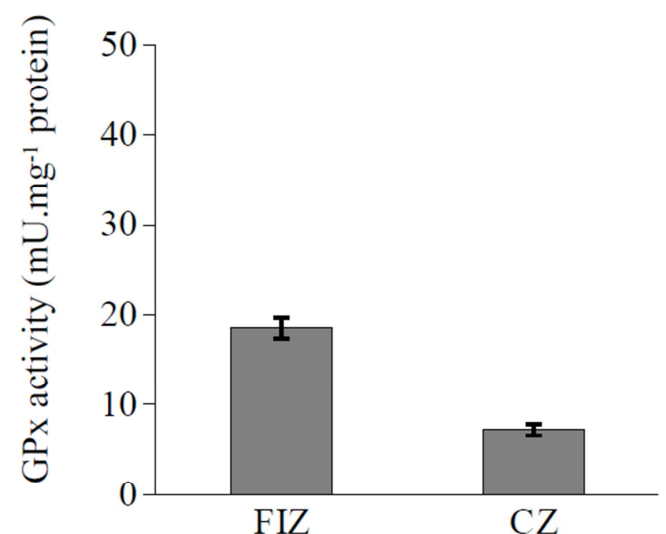

Fig. 2: Spectrophotometric analysis of GPx activity in Anemonia viridis and zooxanthellae. A) Ectoderm (E), endoderm (D) and mitochondrial fraction (M). B) Freshly isolated zooxanthellae (FIZ) and cultured zooxanthellae (CZ). Data are represented as means \pm S.E.M of four independent analyses. Bars marked with the same letters are not significantly different from one another $(\mathrm{p}<0.05$, Nemenyi test).

\subsection{GPx activity staining on native gels}

260 To determine GPx electrophoretype diversity in the various A. viridis compartments, different amounts of protein extract were resolved by native PAGE staining for GPx activities. Fig. 3 shows a representative tissue-specific electrophoresis pattern of GPx activity. The different isoforms, revealed as achromatic bands, were numbered in order of their migration distance. In the ectoderm, two bands were detected. These bands, named electrophoretypes 1 and 2, were also detected in the endoderm extract with identical migration characteristics. In the endoderm, a third band, less intense than the two others, was observed below electrophoretype 2. For the animal mitochondrial fraction, only one band was detected, at the same migration distance as electrophoretype 1 of the 
ectoderm and endoderm extracts. The GPX patterns of the freshly isolated and cultured zooxanthellae underlined the major differences between their two life-styles. In freshly isolated zooxanthellae, at least 7 distinct electrophoretypes were seen with different intensities, with electrophoretypes 2, 4 and 6 showing the highest band intensities. In cultured zooxanthellae, GPx activities were characterized by 4 electrophoretypes, with intense electrophoretype 1 activity.

274 Surprisingly, this staining method also revealed dark chromatic bands in the animal fraction, which 275 could hide the presence of additional GPx activities (Fig. 3). In order to characterize the dark 276 chromatic bands, we performed additional GP $\mathrm{X}_{\mathrm{X}}$ native PAGE assays in the presence of new internal standards: Escherichia coli MnSOD (S-5639), yeast glutathione reductase (G-3664), horseradish peroxidase (HRP) (P-8250) and bovine catalase (C-9322). No correlation between the dark chromatic bands and the tested standards was seen (data not shown).

A

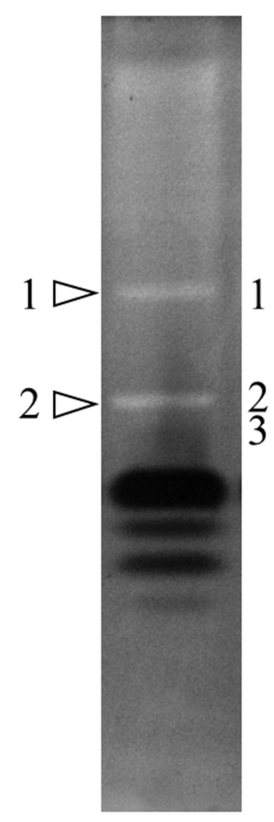

$\mathrm{C}$

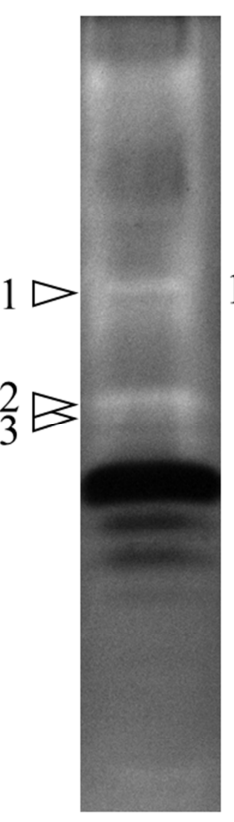

$\mathrm{D}$

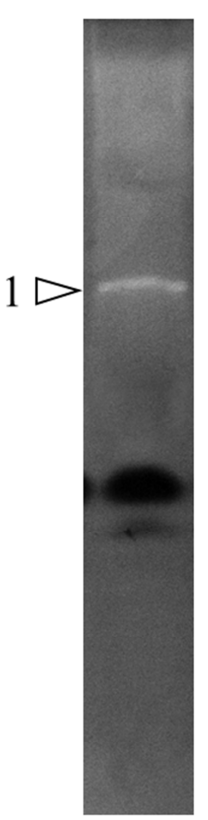

M

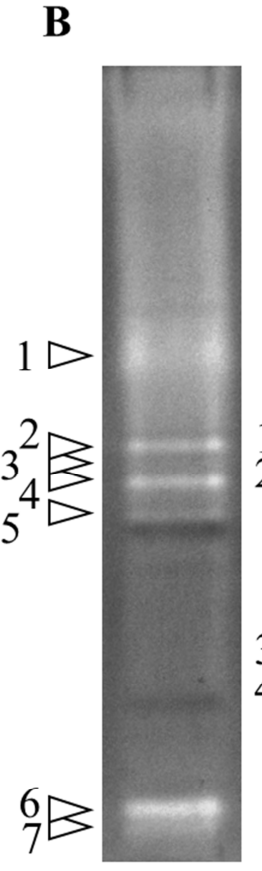

FIZ

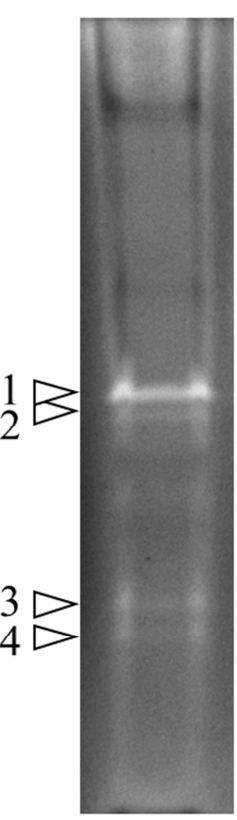

$\mathrm{CZ}$

282 Fig. 3: GPx electrophoresis patterns in compartements of Anemonia viridis and zooxanthellae. A) 283 ectoderm (C), endoderm (D) and mitochondrial fraction (M) were loaded onto 10\% resolving native 284 PAGE with $100 \mu \mathrm{g}, 200 \mu \mathrm{g}$ and $200 \mu \mathrm{g}$ of protein, respectively. B) Cultured zooxanthellae (CZ) and freshly isolated zooxanthellae (FIZ) were loaded onto $10 \%$ resolving native PAGE with $150 \mu \mathrm{g}$ of protein. White arrows indicated the GPx band activities. 
290 GPx activities were followed in the various A. viridis compartments during the $+9^{\circ} \mathrm{C}$ heat stress 291 (Fig. 4). While heat stress induced the sea anemone to bleach [27], GPx activity did not reveal 292 significant modification during the 15 days of stress, irrespective of symbiosis compartment, i.e. 293 ectoderm, endoderm or freshly isolated zooxanthellae (Friedman ANOVA, p>0.05). In addition, 294 GPX eletrophoretype diversity in the different compartments did not show modification in response 295 to stress (data not shown).

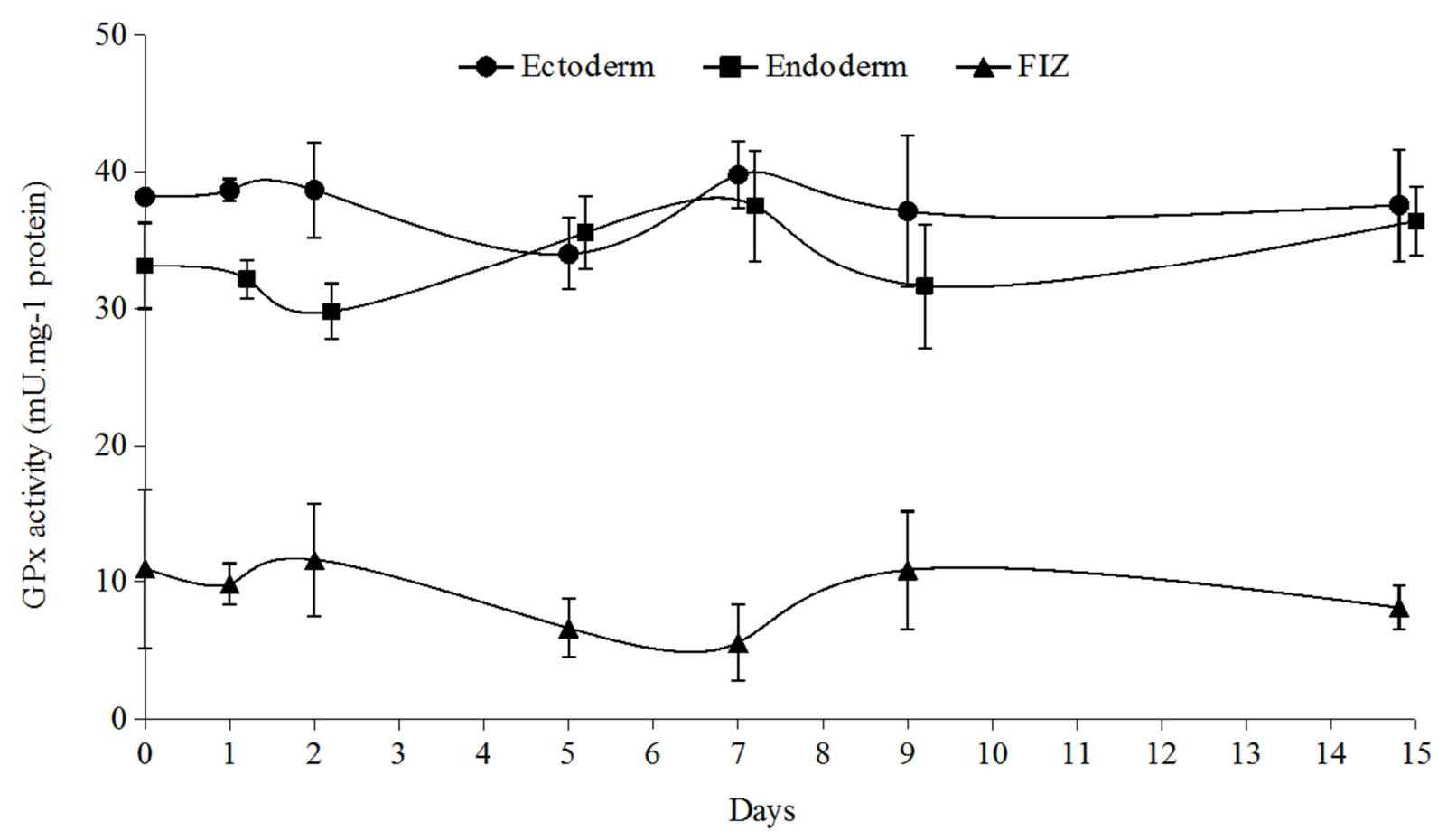

298 Fig. 4: Quantitative evaluation of the GPx activity during thermal stress in Anemonia viridis. 299 Spectrophotometric analysis of GPx activity was followed during the $+9{ }^{\circ} \mathrm{C}$ heat stress in the 300 various A. viridis compartments: ectoderm, endoderm and freshly isolated zooxanthellae (FIZ). 301 Data are represented as means \pm S.E.M of three independent analyses. 
305 To protect and fight against oxidative stress, symbiotic cnidarians have developed adaptive mechanisms thanks to the presence of antioxidant defenses. The efficiency of the response depends on the equilibrium of three detoxifying enzymes, which are the cornerstones of this protection: superoxide dismutase (SOD), peroxidase including glutathione peroxidase (GPx), and catalase (CAT). Many studies of SOD and CAT have highlighted their roles in the maintenance and disruption of cnidarian-dinoflagellate symbioses, but few extensive studies of GPx in symbiotic cnidarians have been reported $[3,28,44]$.

In the present study, we report the first identification and characterization of the GPx isoform repertoire in the transcriptome of $A$. viridis and the genome of two others cnidarians, $N$. vectensis and A. digitifera. Phylogenetic analyses showed the presence in Cnidaria of the 7 main metazoan GPx classes (Fig. 1). This analysis confirmed that the common ancestor diverged in two groups, GPx $7 / 4$ and GPx1/2/3/5/6, followed by multiple duplication events in the early stage of GPx evolution [21,45]. A comparison between the non-symbiotic cnidarian N. vectensis and the two symbiotic cnidarians, A. viridis and A. digitifera, highlights a higher number of GPx transcripts in these symbiotic species, with $N$. vectensis lacking GPx1/2 and GPx4. This trend could be correlated to an adaptation to the highly oxidative state encountered by these symbiotic organisms, and which is controlled by a diverse array of antioxidant defenses as already demonstrated with respect to SOD diversity $[13,28]$, or alternatively by the selection in $N$. vectensis of other $\mathrm{H}_{2} \mathrm{O}_{2}$-scavenging enzymes, such as catalases or other peroxidases. In Symbiodinium sp., the GPx transcripts examined showed less diversification, with two major evolutive groups within the GPx7/4 branch.

In metazoans, different GPx isoforms have specific cellular and subcellular localizations, and specific reducing functions [19,21]. The phenotypic role of the A. viridis GPx repertoire was determined with protein extracts specifically isolated from both animal epithelia and the symbiont, enabled by a method that readily separates the tissue layers. The qualitative analysis of GPx by electrophoretic method, conducted for the first time in a cnidarian by native PAGE, revealed the presence of several active GPx isoforms. At least three active GPx isoforms were observed in the animal tissues, with two isoforms identified in both ectodermal and endodermal tissues. However,

334 the presence of dark chromatic bands in animal epithelia, possibly hiding additional GPx proteins, prevented the fully characterization of the GPx diversity pattern in the animal tissues.

336 Complementary studies have to be carried out to determine the nature of this sharp reduction of 
revealing the activity of enzymes such as cystathionine gamma-lyase, methionine gamma-lyase and cysteine lyase (Ukai and Sekiya, 1997). Among the three active GPx isoforms, the identification of the electrophoretype 1 in the mitochondrial extract, suggests its specificity to this subcellular compartment. The mitochondrial respiratory chain is the second main producer of ROS, so it was unsurprising to measure GPx activities in animal extracts enriched in mitochondria. The

343 electrophoretype 1 could correspond to AviridisGPxa or AviridisGPxj, for which phylogenetic 344 analysis suggested their close affiliation to the mitochondrial GPx1 or GPx4 isoforms [50]. With respect to the symbionts, the absence of dark chromatic bands in both symbiont fractions allows to identify the complete pattern of their GPx diversities. Cultured zooxathellae possessed at least 4 distincts electrophoretypes and freshly isolated zooxanthellae possessed at least 7 distinct electrophoretypes that could correspond to different isoforms of the four Symbiodinium GPx sequences found in the transcriptome.

With regards to the similarity between host and the symbiont activities, one interesting result was the presence of a common band, for electrophoretype 2, in the two symbiotic partners. The molecular characterization of these proteins could increase our knowledge of the mechanisms that maintain life in symbiosis and the possible exchanges between partners. The sequencing of these GPx activity bands could elucidate whether the shared band between host and symbiont may result from lateral transfer of genes or proteins; several such cases exist, and transfer of APx and MnSOD has been hypothesised [55,56]. Another element supporting this hypothesis is the, recent genome analyses that have highlighted similarities between the genomes of the coral Acropora digitifera and the symbiotic dinoflagellate Symbiodinium kawagutii [57].

The quantitative analysis by spectrophotometry revealed that the ectodermal and endodermal fractions displayed the highest GPx activities, with the zooxanthellae displaying two times less activity (Fig. 2). These results corroborate the host and symbiont transcript diversity (Fig.1), and a previous study of GPx immunolocalization in A. viridis tissue [24]. Moreover, contrary to the direct ROS enzymatic defenses (i.e. CAT and ascorbate peroxidase (APx, EC 1.11.1.11)), GPx4 has an important affinity for fats and lipids, and can interact with lipophilic substrates such as peroxidized phospholipids and cholesterol [46,47]. Thus, the higher activities observed in the animal can be correlated to the significant presence of highly polyunsaturated fatty acids in the tissues of the sea anemone compared to the low concentration present in the zooxanthellae $[48,49]$. Despite the localization of the symbiont, the main ROS producer, to the endodermal tissue, our results revealed the same level of GPx activity in both the ectoderm and endoderm. This identical level can be 
catalase owing a high detoxification CCEPTERMANUSCRIPT

375 Concerning the symbiont, a low level of total GPx activity was measured in the freshly isolated zooxanthellae when compared to activity in the animal. The production of $\mathrm{H}_{2} \mathrm{O}_{2}$ and its diffusion through biological membranes to the external seawater [6] may then be partially offset by other scavenging systems of $\mathrm{H}_{2} \mathrm{O}_{2}$, such as CAT or APx, as reported for the algal symbiont $[44,51,52]$. In addition, the analysis of GPx in freshly isolated zooxanthellae and in cultured zooxanthellae revealed that freshly isolated zooxanthellae require more GPx activity. Cultured zooxanthellae may require less protection against $\mathrm{H}_{2} \mathrm{O}_{2}$, since they are affected only by their own production that is released directly into the external seawater, and by other important peroxidase defenses (APx or CAT [52]). Moreover, the presence of a higher proportion of fatty acids (including PUFA) in freshly isolated zooxanthellae than in cultured ones could justify higher GPx protection when the Symbiodinium cells are in hospite [53,54]. Finally, the low level of GPx activity in cultured zooxanthellae could also be related to reduced selenium availability or absorption for GPx activity in the free-living state or, conversely, an increase in selenium uptake in the symbiotic state. No data are currently available but the analysis of the selenium concentration in the cnidarian-zooxanthella symbiosis could provide further insight.

In the view of its strategic localization in both partners, GPx may play a key role in symbiotic equilibrium and adaptation to global temperature increase, especially since GPx have demonstrated to be heat-stress inducible, as in mammals [58] and invertebrates [59]. Moreover, in a recent study, we investigated the transcriptomic response to thermal stress in $A$. viridis and found that the transcription of some GPx was repressed under heat stress [26], but in the present study we showed no modification of protein expression during heat stress. An identical result has also been observed by Richier et al. [4,13] for SOD activity during the same heat stress in A. viridis. Thus, both electrophoretype patterns and GPx activities, which are stable under heat stress, suggest an overall constitutive and non-inducible activity, which may be an inherent adaptation to a symbiotic lifestyle. Taken together, these results suggest that the absence of antioxidant enzyme activation during stress is the result of a preconditioning of the animal by daily endogenous oxygen variations that push the antioxidant system to the upper limit of its plasticity. 
404

405 This work was supported by a doctoral fellowship from the French Ministère de l'Enseignement 406 Supérieur et de la Recherche [33071-2008 to A.P.] and by the CNRS fundings through APEGE407 PLASTiC project. The authors are grateful to Brigitte Sibille to her technical advice about 408 mitochondrial extraction and to Brigitte Poderini, for sea anemones care. The authors are also 409 grateful to Daniela Catania and Simon Davy, for English reviewing of the manuscript.

\section{Conflict of interest}

412 The authors declare no conflict of interest. 
415 [1] C. B. Cook, Metabolic interchange in algae-invertebrate symbiosis, Int. Rev. Cytol. (1983).

416 [2] B. Halliwell, J. M. C. Gutteridge, Free Radicals in Biology and Medicine, Oxford Science 417 Publications, Oxford, 1999, p. 936.

418 [3] J. A. Dykens, J. M. Shick, C. Benoit, G. R. Buettner, G. W. Winston, Oxygen radical production in the sea anemone Anthopleura elegantissima and its endosymbiotic algae, J. Exp. Biol. 168 (1992) 219-241.

[4] S. Richier, P. L. Merle, P. Furla, D. Pigozzi, F. Sola, D. Allemand, Characterization of superoxide dismutases in anoxia-and hyperoxia-tolerant symbiotic cnidarians, Biochim. Biophys. Acta 1621 (2003) 84-91.

[5] E. Saragosti, D. Tchernov, A. Katsir, Y. Shaked, Extracellular production and degradation of superoxide in the coral Stylophora pistillata and cultured Symbiodinium, PLoS One 5 (2010) e12508.

[6] R. Armoza-Zvuloni, Y. Shaked, Release of hydrogen peroxide and antioxidants by the coral Stylophora pistillata to its external milieu, Biogeosciences 11 (2014) 4587-4598.

[7] V. Weis, R. Levine, Differential protein profiles reflect the different lifestyles of symbiotic and aposymbiotic Anthopleura elegantissima, a sea anemone from temperate waters, J. Exp. Biol. 199 (1996) 883-892.

[8] D. Allemand, P. Furla, S. Bénazet-Tambutté, Mechanisms of carbon acquisition for endosymbiont photosynthesis in Anthozoa, Can. J. Botany. 76 (1998) 925-941.

[9] P. Furla, S. Richier, D. Allemand, Physiological adaptation to symbiosis in cnidarians, In Coral Reefs: An Ecosystem in Transition, Springer Netherlands 2011, pp 187-195.

[10] B. E. Brown, Coral bleaching: causes and consequences, Coral reefs 16 (1997) S129-S138.

[11] A. E. Douglas, Coral bleaching—how and why? Mar. Pollut. Bull. 46 (2003) 385-392.

[12] O. Hoegh-Guldberg, Climate change, coral bleaching and the future of the world's coral reefs, Mar. Freshwater Res. 50 (1999) 839-866.

[13] S. Richier, P. Furla, A. Plantivaux, P. L. Merle, D. Allemand, Symbiosis-induced adaptation to oxidative stress, J. Exp. Biol. 208 (2005) 277-285.

[14] S. Richier, J. M. Cottalorda, M. M. Guillaume, C. Fernandez, D. Allemand, P. Furla, Depthdependant response to light of the reef building coral, Pocillopora verrucosa: Implication of oxidative stress, J. Exp. Mar. Biol. Ecol. 357 (2008) 48-56.

[15] A. Pey, T. Zamoum, D. Allemand, P. Furla, P. L. Merle, Depth-dependant thermotolerance of the symbiotic Mediterranean gorgonian Eunicella singularis: Evidence from cellular stress markers, J. Exp. Mar. Biol. Ecol. 404 (2011) 73-78. 
[16] C. A. Downs, K. E. McDougall, C. M. Woodley, J. E. Fauth, R. H. Richmond, A. Kushmaro,

S. W. Gibb, Y. Loya, G. K. Ostrander, E. Kramarsky-Winter, Heat-stress and light-stress induce different cellular pathologies in the symbiotic dinoflagellate during coral bleaching, PloS one 8 (2013) e77173.

[17] J. M. Shick, J. A. Dykens, Oxygen detoxification in algal-invertebrate symbioses from the Great Barrier Reef, Oecologia 66 (1985) 33-41.

[18] A. Plantivaux, P. Furla, D. Zoccola, G. Garello, D. Forcioli, S. Richier, P. L. Merle, E. Tambutté, S. Tambutté, D. Allemand, Molecular characterization of two CuZn-superoxide dismutases in a sea anemone, Free Radical Bio. Med. 37 (2004) 1170-1181.

[19] R. Brigelius-Flohe, M. Maiorino, Glutathione peroxidases, Biochim. Biophys. Acta 1830 (2013) 3289-3303.

[20] G. J. Den Hartog, G. R. Haenen, E. Vegt, W. J. van der Vijgh, A. Bast, Superoxide dismutase: the balance between prevention and induction of oxidative damage, Chem.-Biol. Interact. 145 (2003) 33-39.

[21] R. Margis, C. Dunand, F. K. Teixeira, M. Margis-Pinheiro, Glutathione peroxidase family-an evolutionary overview, Febs Journal 275 (2008) 3959-3970.

[22] H. Imai, Y. Nakagawa, Biological significance of phospholipid hydroperoxide glutathione peroxidase (PHGPx, GPx4) in mammalian cells, Free Radical Bio. Med. 34 (2003) 145-169.

[23] S. Toppo, L. Flohé, F. Ursini, S. Vanin, M. Maiorino, Catalytic mechanisms and specificities of glutathione peroxidases: variations of a basic scheme. Biochim. Biophys. Acta 1790 (2009) 1486-1500.

[24] J. M. Hawkridge, R. K. Pipe, B. E. Brown, Localisation of antioxidant enzymes in the cnidarians Anemonia viridis and Goniopora stokes, Mar. Biol. 137 (2000) 1-9.

[25] P. Ganot, A. Moya, V. Magnone, D. Allemand, P. Furla, C. Sabourault, Adaptations to endosymbiosis in a cnidarian-dinoflagellate association: differential gene expression and specific gene duplications, PLoS genetics 7 (2011) e1002187.

[26] A. Moya, P. Ganot, P. Furla, C. Sabourault, The transcriptomic response to thermal stress is immediate, transient and potentiated by ultraviolet radiation in the sea anemone Anemonia viridis, Mol. Ecol. 21 (2012) 1158-1174.

[27] R. R. Guillard, J. H. Ryther, Studies of marine plankton diatoms. I. Cyclotella nana Hustedt and Detonula confervacea (Cleve) Gran, Can. J. Microbiol. 8 (1962) 229-239.

[28] S. Richier, P. L. Merle, P. Furla, D. Pigozzi, F. Sola, D. Allemand, Characterization of superoxide dismutases in anoxia-and hyperoxia-tolerant symbiotic cnidarians, Biochim. Biophys. Acta 1621 (2003) 84-91.

[29] M. M. Bradford, A rapid and sensitive method for the quantitation of microgram quantities of 
protein utilizing the principle of protein-dye binding, Anal. Biochem. 72 (1976) 248-254.

484

[30] D. Paglia, W. N. Valentine, Studies on the quantitative and qualitative characterization of erythrocyte glutathione peroxidase, J. Lab. Clin. Med. 70 (1967) 158-69.

[31] C. J. Weydert, J. J. Cullen, Measurement of superoxide dismutase, catalase and glutathione peroxidase in cultured cells and tissue, Nat. Protoc. 5 (2010) 51-66.

[32] C. L. Lin, H. J. Chen, W. C. Hou, Activity staining of glutathione peroxidase after electrophoresis on native and sodium dodecyl sulfate polyacrylamide gels, Electrophoresis 23 (2002) 513-516.

[33] A. M. Bolger, M. Lohse, B. Usadel, Trimmomatic: a flexible trimmer for Illumina sequence data, Bioinformatics.btu170, (2014).

[34] M. G. Grabherr, B. J. Haas, M. Yassour, J. Z. Levin, D. A. Thompson, I. Amit, X. Adiconis, L. Fan, R. Raychowdhury, Q. D. Zeng, Z. Chen, E. Mauceli, N. Hacohen, A. Gnirke, N. Rhind, F. di Palma, B. W. Birren, C. Nusbaum, K. Lindblad-Toh, N. Friedman, A. Regev, Full-length transcriptome assembly from RNA-Seq data without a reference genome, Nat. Biotechnol. 29 (2011) 644-U130.

[35] M. Maiorino, F. Ursini, V. Bosello, S. Toppo, S. C. Tosatto, P. Mauri, K. Becker, A. Roveri1, C. Bulato, L. Benazzi, A. De Palma, L. Flohé, The thioredoxin specificity of Drosophila GPx: a paradigm for a peroxiredoxin-like mechanism of many glutathione peroxidases, J. Mol. Biol. 365 (2007) 1033-1046.

[36] S. Toppo, S. Vanin, V. Bosello, S. C. Tosatto, Evolutionary and structural insights into the multifaceted glutathione peroxidase (Gpx) superfamily, Antioxid. Redox. Sign. 10 (2008) 15011514.

[37] C. Shinzato, E. Shoguchi, T. Kawashima, M. Hamada, K. Hisata, M. Tanaka, M. Fujie, M. Fujiwara, R. Koyanagi, T. Ikuta, A. Fujiyama, D. J. Miller, N. Satoh, Using the Acropora digitifera genome to understand coral responses to environmental change, Nature 476 (2011) 320-323.

[38] N. H. Putnam, M. Srivastava, U. Hellsten, B. Dirks, J. Chapman, A. Salamov, A. Terry, H. Shapiro, E. Lindquist, V. V. Kapitonov, J. Jurka, G. Genikhovich, I. V. Grigoriev, S. M. Lucas, R. E. Steele, J. R. Finnerty, U. Technau, M. Q. Martindale, D. S. Rokhsar, Sea anemone genome reveals ancestral eumetazoan gene repertoire and genomic organization, Science 317 (2007) 8694.

[39] T. Bayer, M. Aranda, S. Sunagawa, L. K. Yum, M. K. DeSalvo, E. Lindquist, M. A. Coffroth, C. R. Voolstra, M. Medina, Symbiodinium transcriptomes: genome insights into the dinoflagellate symbionts of reef-building corals, PloS one, 7 (2012) e35269.

[40] E. Shoguchi, C. Shinzato, T. Kawashima, F. Gyoja, S. Mungpakdee, R. Koyanagi, T. 
Takeuchi, K. Hisata, M. Tanaka, M. Fujiwara, M. Hamada, A. Seidi, M. Fujie, T. Usami, H.

Goto, S. Yamasaki, N. Arakaki, Y. Suzuki, S. Sugano, A. Toyoda, Y. Kuroki, A. Fujiyama, M.

Medina, M. A. Coffroth, D. Bhattacharya, N. Satoh, Draft assembly of the Symbiodinium minutum nuclear genome reveals dinoflagellate gene structure, Curr. Biol. 23 (2013) 1399-1408.

[41] N. Fawal, Q. Li, B. Savelli, M. Brette, G. Passaia, M. Fabre, C. Mathé, C. Dunand, PeroxiBase: a database for large-scale evolutionary analysis of peroxidases, Nucleic Acids Res. 41 (2013) D441-D444.

[42] N. Galtier, M. Gouy, C. Gautier, SEAVIEW and PHYLO_WIN: two graphic tools for sequence alignment and molecular phylogeny, Computer applications in the biosciences: CABIOS 12 (1996) 543-548.

[43] J. H. Zar, Biostatistical analysis, 4th edition. Prentice-Hall, Upper Saddle River, New Jersey, 1999.

[44] P. L. Merle, C. Sabourault, S. Richier, D. Allemand, F. Furla, Catalase characterization and implication in bleaching of a symbiotic sea anemone, Free Radical Bio. Med. 42 (2007) 236-246.

[45] Y. A. Bae, G. B. Cai, S. H. Kim, Y. G. Zo, Y. Kong, Modular evolution of glutathione peroxidase genes in association with different biochemical properties of their encoded proteins in invertebrate animals, BMC Evol. Biol. 9 (2009) 72.

[46] F. Ursini, M. Maiorino, C. Gregolin, The selenoenzyme phospholipid hydroperoxide glutathione peroxidase, Biochim. Biophys. Acta 839 (1985) 62-70.

[47] J. P. Thomas, M. Maiorino, F. Ursini, A. W. Girotti, Protective action of phospholipid hydroperoxide glutathione-peroxidase against membrane-damaging lipid-peroxidation - in situ reduction of phospholipid and cholesterol hydroperoxides, J. Biol. Chem. 265 (1990) 454-461.

[48] A. D. Harland, L. M. Fixter, P. S. Davies, R. A. Anderson, Distribution of lipids between the zooxanthellae and animal compartment in the symbiotic sea anemone Anemonia viridis: Wax esters, triglycerides and fatty acids, Mar. Biol. 110 (1991) 13-19.

[49] J. Revel, L. Massi, M. Mehiri, M. Boutoute, P. Mayzaud, L. Capron, C. Sabourault, Differential distribution of lipids in epidermis, gastrodermis and hosted Symbiodinium in the sea anemone Anemonia viridis, Comp. Biochem. Physiol. A Mol. Integr. Physiol. 191 (2015) 140151.

[50] J. R. Drevet, The antioxidant glutathione peroxidase family and spermatozoa: a complex story, Mol. Cell. Endocrinol. 250 (2006) 70-79.

[51] M. P. Lesser, Elevated temperatures and ultraviolet radiation cause oxidative stress and inhibit photosynthesis in symbiotic dinoflagellates, Limnol. Oceanogr. 41 (1996) 271-283.

[52] M. P. Lesser, J. M. Shick, Effects of irradiance and ultraviolet radiation on photoadaptation in the zooxanthellae of Aiptasia pallida: primary production, photoinhibition, and enzymic 
defenses against oxygen toxicity, Mar. Biol. 102 (1989) 243-255.

554 [53] H. K. Chen, S. N. Song, L. H. Wang, A. B. Mayfield, Y. J. Chen, W. N. U. Chen, C. S. Chen, A Compartmental Comparison of Major Lipid Species in a Coral-Symbiodinium Endosymbiosis: Evidence that the Coral Host Regulates Lipogenesis of Its Cytosolic Lipid Bodies, PloS one 10 (2015).

[54] L. H. Wang, H. K. Chen, C. S. Jhu, J. O. Cheng, L. S. Fang, C. S. Chen, Different strategies of energy storage in cultured and freshly isolated Symbiodinium sp, J. Phycol. (2015).

[55] M. Habetha, T. C. Bosch, Symbiotic Hydra express a plant-like peroxidase gene during oogenesis, J. Exp. Biol. 208 (2005) 2157-2165.

[56] P. Furla, S. Richier, P. L. Merle, G. Garello, A. Plantivaux, D. Forcioli, D. Allemand, Roles and origins of superoxide dismutases in a symbiotic cnidarians, In: Organisms SEaEGoCR (ed) 11th international coral reef symposium, Fort Lauderdale, 2008.

[57] S. Lin, S. Cheng, B. Song, X. Zhong, X. Lin, W. Li, L. Li, Y. Zhang, H. Zhang, Z. Ji, M. Cai, Y. Zhuang, X. Shi, L. Lin, L. Wang, Z. Wang, X. Liu, S. Yu, P. Zeng, H. Hao, Q. Zou, C. Chen, Y. Li, Y. Wang, C. Xu, S. Meng, X. Xu, J. Wang, H. Yang, D. A. Campbell, N. R. Sturm, S. Dagenais-Bellefeuille, D. Morse, The Symbiodinium kawagutii genome illuminates dinoflagellate gene expression and coral symbiosis, Science 350 (2015) 691-694.erdale.

[58] M. Ando, K. Katagiri, S. Yamamoto, S. Asanuma, M. Usuda, I. Kawahara, K. Wakamatsu, Effect of hyperthermia on glutathione peroxidase and lipid peroxidative damage in liver, J. Therm. Biol. 19 (1994) 177-185.

[59] X. N. Verlecar, K. B. Jena, G. B. N. Chainy, Biochemical markers of oxidative stress in Perna viridis exposed to mercury and temperature, Chem.-Biol. Interact. 167 (2007) 219-226. 